\title{
Analisis Kinerja Apotek yang Bekerjasama dengan Jaminan Kesehatan Nasional (JKN) dari Perspektif Keuangan dan Pelanggan di Kota Makassar
}

\author{
Ilham Maulana*1, Yusi Anggraini ${ }^{1}$ and Aritonang $^{1}$ \\ ${ }^{1}$ Program Magister Farmasi, Fakultas Farmasi, Universitas Pancasila, DKI Jakarta, Indonesia \\ *E-mail: ilhammaulana_23@yahoo.co.id
}

\begin{abstract}
This study aims to measure the performance of pharmacy inan in the (National Health Insurance) JKN era based ona financial perspective with parameters the net profit margin and pharmacy income. And the perspective customer is within the parameters of the quality pharmacy service in this matter tangibles, reliability, responsiveness, assurance, and empathy in a pharmacy in Makassar city on customer satisfaction pharmacy and the number of customer visits to the pharmacy. This study employed analytic quantitave and qualitative methods. The research sample consisted of 5 apothecary 99 pharmacy customers. The study results on the financial perspektive show that the net profit margin pharmachie's 2014 average value was 6,31\% and that by 2018 it was 6,93\% and the pharmacies were virtually in good condition. In the pharmacies income there are 2 pharmachies that have suffered a decline in the pharmacy's turnover and 3 pharmachies have experienced an increase in the 2018 over 2014. As for the number of pharmcy customers, there is 1 pharmacy that has a decline and 4 pharmacy that have seen an increase in the number of customer visits to the pharmcy in 2018 over 2014.And the customer perspective, the test $F$ show that the F Count of 5,111 and F Tables 2,31, so that it can be reached the conclusion that the quality of service made up of both reliabilty, tangible, responsiveness, assurance and emphaty affect the satisfaction of the pharmacies customers in the city of Makassar.
\end{abstract}

Keywords: financial perspective, customer satisfaction, pharmacy service's quality, National Health Insurance

\begin{abstract}
ABSTRAK
Penelitian ini bertujuan untuk mengukur kinerja apotek dalam era JKN berdasarkan perspektif keuangan dengan parameter, net profit margin, omset apotek. Dan perspektif pelanggan yaitu kualitas pelayanan apotek dalam hal ini fasilitas berwujud/ fasilitas apotek, kehandalan, daya tanggap, jaminan, dan empati di apotek di kota Makassar terhadap kepuasan pelanggan apotek, serta jumlah kunjungan pelanggan ke apotek. Penelitian ini menggunakan metode analitik kuantitatif dan kualitatif. Sampel penelitian berjumlah 5 apotek JKN serta 99 pelanggan apotek JKN. Hasil penelitian pada perspektif keuangan menunjukan bahwa rata-rata nilai net profit margin apotek tahun tahun 2014 adalah 6,31\% dan pada tahun 2018 adalah 6,93\% dan bisa dikatakan dalam kondisi baik. Pada omset apotek terdapat 2 apotek yang mengalami penurunan omset apotek dan 3 apotek yang mengalami kenaikan omset apotek tahun 2018 atas tahun 2014.Sedangkan pada jumlah kunjungan pelanggan apotek terdapat 1 apotek yang mengalami penurunan dan 4 apotek yang mengalami kenaikan jumlah kunjungan pelanggan ke apotek tahun 2018 atas tahun 2014. Dan dalam perspektif pelanggan, hasil uji F menunjukan bahwa F Hitung sebesar 5,111 dan F Tabel sebesar 2,31 sehingga dapat diambil kesimpulan bahwa kualitas pelayanan yang terdiri dari kehandalan, fasilitas berwujud/ fasilitas apotek, daya tanggap, jaminan, dan empati berpengaruh terhadap kepuasan pelanggan apotek di kota Makassar.
\end{abstract}

Kata kunci: Perspektif kauangan, kepuasan pelanggan, kualitas pelayanan, Jaminan Kesehatan Nasional 


\section{Pendahuluan}

Pembangunan kesehatan diarahkan untuk meningkatkan kualitas sumber daya manusia, kualitas hidup manusia dalam keberlangsungan kegiatan yang dilakukan. Pembangunan kesehatan diharapkan dapat menigkatkan kesejahteraan keluarga masing-masing serta diharapkan dapat meningkatkan kesadaran masyarakat akan pentingnya kesehatan.

Undang-undang No. 40 tahun 2004 mengenai sistem jaminan sosial nasional (SJSN) mengamanatkan bahwa jaminan sosial wajib bagi seluruh warga Indonesia. Pada bulan Januari tahun 2014 sistem kesehatan di Indonesia mulai diselenggarakan dengan nama program Jaminan Kesehatan Nasional (JKN), dan yang menyelanggarakannya adalah Badan Penyelenggara Jaminan Sosial (BPJS Kesehatan) [1].

Berdasarkan Peraturan Menteri Kesehatan RI No. 9 tahun 2017, Apotek adalah sarana pelayanan kefarmasian, tempat dilakukan praktek oleh apoteker. Apotek harus memiliki apoteker sesuai dengan peraturan yang telah ditetapkan oleh Menteri Kesehatan Republik Indonesia melalui Permenkes Nomor 9 Tahun 2017 yang memiliki kewajiban dalam menjalankan kegiatan pelayanan terhadap pelanggan dan tanggug jawab dalam menjalankan standar profesinya [2].

Apotek yang telah bekerja sama dengan BPJS berkewajiban melayani dan menerima pasien yang terdaftar di BPJS dan melakukan upaya kesehatan secara komperehensif. Pada Permenkes No.71 Tahun 2013, dalam pasal 3 disebutkan bahwa pelayanan kefarmasian adalah sebagai pelayanan penunjang bagi pelayanan kesehatan. Partisipasi dalam sistem jaminan kesehatan nasional (JKN) dapat dilakukan dengan menjadi apotek fasilitas kesehatan tingkat pertama yang bekerja sama langsung dengan JKN [3].

Apotek sebagai salah satu sarana pelayanan penunjang kesehatan berperan sebagai seperti perusahaan pengecer (retail) barang farmasi, yang komoditasnya terdiri dari perbekalan farmasi (obat dan bahan obat) dan perbekalan kesehatan, serta sebagai tempat untuk memperoleh informasi kesehatan. Pada perkembangannya, apotek tidak terlepas dari adanya persaingan yang semakin keras dan global [4].

Pada saat ini usaha di bidang farmasi termasuk dalam perapotekan mempunyai dua profil yaitu yang pertama merupakan suatu institusi profesi yang memerankan peranan penting sebagai anggota tim kesehatan dan yang kedua merupakan pengusaha dalam perdagangan obat [5]. Apoteker sebagai pengelola apotek tidak cukup hanya dengan berbekal ilmu kefarmasian saja. Melainkan harus dibekali pula dengan pengetahuan tentang ekonomi termasuk manajemen pemasaran farmasi, karena mengelola sebuah apotek sama halnya dengan mengelola sebuah perusahaan [4].

Balanced Scrorecard merupakan salah satu sistem pengukuran kinerja yang terdiri dalam empat perspektif yaitu keuangan, pelanggan (customer), proses pelayanan, serta pembelajaran dan pertumbuhan. Pemakaian penilaian kinerja perspektif keuangan belum cukup mewakili dan menyimpulkan apakah kinerja yang dimiliki suatu perusahaan sudah baik atau belum. Sehingga dibutuhkan perspektif non keuangan seperti perspektif customer (pelanggan) [6].

Kepuasan pelanggan merupakan perasaan senang yang muncul di dalam diri seseorang setelah mendapat pelayanan yang diterima atau dialami secara langsung. Dalam konteks pelayanan kefarmasian apotek, salah satu cara untuk mengetahui kepuasan pelanggan apotek yaitu dengan metode SERVQUAL (Service Quality.) Dengan cara membuat survey penilaian kepuasan pelanggan secara komprehensif bagi pelayanan di bidang barang dan jasa yang mengutamakan aspek pelayanan. Analisis kepuasan pelanggan dilakukan bedasarkan lima dimensi kualitas layanan, yakni responsiveness (ketanggapan), reliability (kehandalan), assurance (jaminan), empathy (empati), dan tangible (bukti fisik/fasilitas apotek) [7].

Penelitian ini bertujuan untuk mengukur perbedaan kinerja apotek berdasarkan perspektif keuangan berdasarkan parameter net profit margin apotek dan omset apotek dalam era JKN serta perspektif pelanggan dengan parameter kualitas pelayanan terhadap kepuasan pelanggan apotek di kota Makassar dalam era JKN.

\section{Metode Penelitian}

Metode penelitian yang digunakan adalah metode kuantitatif yaitu secara observasional crossectional, dan metode kualitatif dengan cara wawancara mendalam, yang pengumpulan data menggunakan metode survei kepada seluruh responden dalam penelitian ini. Data perspektif keuangan untuk mengetahui nilai net profit margin apotek dan data jumlah kunjungan pelanggan apotek di dapatkan langsung dari dokumen apotek tahun 2014 sampai 2019. Data perspektif pelanggan untuk mengetahui pengaruhya pelayanan kefarmasian sebagai variabel independen $(X)$ terhadap kepuasan pelanggan sebagai variabel dependen $(Y)$ di apotek dalam era Jaminan Kesehatan Nasional diambil melalui kuesioner yang dibagikan terhadap pelanggan apotek. Dalam penelitian ini, pengambilan data dilakukan di 5 apotek yang bekerja sama dengan JKN di kota Makassar. Penelitian dilaksanakan pada bulan April-Juni 2019. Kriteria Inklusi yaitu pelanggan pelanggan yg sudah pernah ke apotek, pelanggan apotek yang berusia di atas 17 tahun, pelanggan apotek yang datang untuk membeli obat, dan pelanggan apotek yang datang untuk menebus resep dokter. Kriteria eksklusi yaitu pelanggan yang tidak mampu dalam mengisi kuesioner, pelanggan dengan umur dibawah 17 tahun pelanggan apotek yang tidak jadi membeli obat di apotek tersebut. 


\section{Hasil dan Pembahasan}

\subsection{Karakteristik apotek}

Berdasarkan data yang diperolah dari Dinas Kesehatan Kota Makassar didapatkan sebagai berikut, apotek RSU sebanyak 49 atau (9\%), apotek RSIA sebanyak 20 (4\%), apotek puskesmas sebanyak 46 atau (9\%), apotek swasta klinik sebanyak 181 (34\%), apotek swasta non klinik non JKN sebanyak 220 atau (41\%) dan apotek JKN sebanyak 15 atau sekitar (3\%). Berdasarkan Omset rata-rata per bulan terdapat 27 apotek dengan omset 0-35 juta per bulan atau sekitar (44\%) dan 21 apotek ber omset 35-70 juta atau sekitar (21\%), dan 13 apotek ber omset $70-150$ juta atau sekitar (21\%).

\subsection{Karakteristik pelanggan apotek}

Berdasarkan jenis kelamin responden terdapat 52 berjenis kelamin laki-laki atau sekitar $(51,49) \%$ dan 47 berjenis kelamin perempuan atau sekitar $(48,51 \%)$. Hal ini menunjukan bahwa sebagian besar pasien yang berkunjung ke apotek yaitu laki-laki sebesar $(51,49 \%)$ sesuai dengan populasi penduduk di kota Makassar yang penduduknya berjenis kelamin laki-laki lebih banyak sedikit dibandingkan dengan penduduk berjeenis kelamin perempuan.

Berdasarkan rentan usia responden yang sering berkunjung ke apotek di kota Makassar paling besar berada pada usia dewasa 18-49 tahun sebanyak 62 orang atau sekitar $(63,37 \%), 20$ orang memiliki usia 49 tahun ke atas atau sekitar $(19,80 \%), 17$ orang memiliki usia remaja 17 tahun atau sekitar $(16,83)$. Berdasarkan rentan usia responden mayoritas pelanggan yang berkunjung ke apotek memiliki usia yang produktif.

Berdasarkan pendidikan terakhir, pendidikan SD sebesar 7 orang atau sekitar $(6,93 \%), 19$ orang memiliki pendidikan SMP atau sekitar $(18,81 \%), 41$ orang memiliki pendidikan SMA atau sekitar $(42,57 \%), 32$ orang memiliki pendidikan Perguruan Tinggi / akademi atau sekitar (31,68\%). Berdasarkan pendidikan terakhir responden sebagian besar pelanggan yang berkunjung ke apotek memiliki pendidikan SMA yang diharapkan responden mempunyai pengetahuan dan kemampuan dalam menjawab butir pernyataan yang ada dalam kuesioner.

Berdasarkan pekerjaan sebagian besar pelanggan yang berkunjung ke apotek memiliki pekerjaan sebagai pegawai swasta sebanyak 29 orang atau sekitar (30,69\%), kemudian memiliki pekerjaan sebagai wiraswasta sebanyak 20 orang atau sekitar $(20,79 \%), 14$ orang memiliki pekerjaan sebagai mahasiswa/mahasiswi atau sekitar $(15,84 \%), 27$ orang memiliki pekerjaan sebagai PNS / TNI / POLRI atau sekitar $(28,71 \%), 7$ orang memiliki pekerjaan sebagai ibu rumah tangga atau sekitar $(6,93 \%)$, dan 2 orang memilih pekerjaan dan lain-lain atau sekitar (1,98\%). Hal ini menunjukan bahwa pelanggan apotek di kota Makassar sebagian besar bekerja sebagai karyawan di perusahaan atau perkantoran.

Berdasarkan tingkat penghasilan, sebagian besar pelanggan yang berkunjung ke apotek memliki penghasilan sebesar diatas Rp. 5.000.000,00 sebanyak 44 orang atau sekitar (43,56\%), 38 orang berpenghasilan Rp. 1.000.000,00 Rp. 5.000.000,00 atau sekitar $(38,61 \%), 17$ orang memiliki penghasilan sebesar dibawah Rp. 1.000.000,00 atau sekitar $(17,82 \%)$.

Berdasarkan frekuensi melakukan kunjungan ke apotek sebagian besar responden melakukan kunjungan ke apotek 25 kali sebanyak 46 orang atau sekitar $(45,54 \%)$, sedangkan responden yang $>5$ kali sebanyak 31 orang atau sekitar $(30,69 \%)$ dan responden yang baru pertama kali berkunjung ke apotek sebesar 22 orang atau sekitar $(23,76 \%)$.

Berdsarakan peruntukan resep 65 orang responden atau sekitar $(64,36 \%)$ membeli obat /menebus obat untuk anak/ keluarganya, sedangkan 25 orang atau sekitar $(24,75 \%)$ membeli obat / menebus obat untuk diri sendiri, dan 9 orang atau sekitar (6,93\%) membeli obat / menebus obat untuk orang lain.

\subsection{Omset apotek}

Dalam penelitian ini terdapat 5 apotek yang berhasil didapatkan data omset pejualan apotek tahun 2014-2018. Apotek-apotek ini adalah apotek telah bekerja sama dengan JKN sejak lama atau bisa dibilang yang terlama. Sedangkan beberapa apotek lain baru mulai bekerja sama dengan JKN pada tahun 2019.

Berdasarkan Tabel 1 terdapat 5 apotek yang bekerja sama dengan JKN. Terdapat 2 apotek yang mengalami penurunan jumlah omset penjualan pada tahun 2018 atas tahun 2014 yaitu apotek AJKN 1 sebesar 55\% dan AJKN 2 sebesar 36\%. Turunnya daya beli pelanggan ke apotek tersebut juga mempengaruhi turunnya jumlah omset penjualan ke apotek tersebut, selain itu perbedaan harga produk dengan apotek lain merupakan salah satu pengaruh pelanggan tidak lagi membeli obat di apotek tersebut. Namun, apotek tersebut sering mengadakan promosi untuk menarik lebih lagi pelanggan serta juga program pelayanan kefarmasian yang di tawarkan juga berbeda dengan apotek swasta.

Sedangkan 3 apotek lainnya mengalami kenaikan jumlah omset penjualan apotek tahun 2018 atas tahun 2014 yaitu apotek AJKN 3 sebesar 101\%, apotek AJKN 4 sebesar $43 \%$, dan AJKN 5 sebesar 19\%. Kenaikan ini dipengaruhi oleh beberapa hal seperti terkenalnya apotek tersebut di masyarakat dengan ciri khasnya itu membuat animo pelanggan yang datang ke apotek bertambah. Serta pelanggan JKN yang juga banyak datang ke apotek tersebut untuk menebus obat. Meningkatnya omset apotek AJKN 3 pada tahun 2018 mencapai 2 kali lipat hal itu dipengaruhi juga oleh meningkatnya jumlah kunjungan pelanggan umum, serta banyaknya pelanggan JKN yang datang ke apotek tersebut, 
dan apotek tersebut merupakan pusat sehingga banyak pelanggan yang diarahkan untuk ke apotek tersebut. Selain itu rekomendasi dokter untuk ke apotek tersebut juga cukup banyak membawa pelanggan untuk kesana.

\subsection{Jumlah kunjungan pelanggan}

Berdasar data pada Tabel 2, terdapat 5 apotek yang bekerja sama dengan JKN yang dimana kelima apotek tersebut menerima pelangggan umum dan pasien JKN. 4 apotek merupakan apotek jejaring yang sudah memiliki nama besar di kota Makassar dan 1 apoteknya adalah apotek swasta. Dalam penelitian ini terdapat 1 apotek yang mengalami penurunan jumlah kunjungan pelanggan yaitu apotek AJKN 2 sebesar 14\% di tahun 2018 atas tahun 2014. Penurunan itu terjadi karena turunnya daya beli ke apotek AJKN 2 yang dimana terjadi persaingan antar apotek di wilayah dekat apotek AJKN 2 tersebut, seperti adanya apotek yang baru muncul dan jam operasionalnya 24 jam dengan menjual obat yang harganya lebih murah. Dikarenakan banyak pelanggan yang mencari murah serta yang ada promosinya sehingga hal itu mempengaruhi di apotek tersebut.
Apotek AJKN 1 mengalami kenaikan sebesar 16\%, sedangkan apotek AJKN 3 mengalami kenaikan yang sangat signifikan yaitu sebesar 299\%, naiknya jumlah kunjungan ini dikarenkan adanya peserta JKN yang diarahkan ke apotek tersebut untuk menebus obatnya di apotek tersebut, dan selain itu pelanggan yang non peserta JKN pun banyak juga yang berkunjung ke apotek tersebut.

Apotek AJKN 4 mengalami kenaikan sebesar 85\%, sama halnya dengan apotek AJKN 3, apotek tersebut juga menerima lebih banyak peserta JKN dibandingkan dengan apotek jejaring yang lain. Selain itu letak apotek nya yang startegis pun juga berpengaruh terhadap kunjungan pelanggan apotek, dan juga dokter yang berpraktek di apotek juga cukup terkenal sehingga membawa lebih banyak pelanggan datang. Dan untuk apotek AJKN 5 yang merupakan satu-satunya apotek swasta yang bekerja sama dengan JKN mengalami kenaikan jumlah pelanggan apotek tahun 2018 atas tahun 2013 sebesar $33 \%$. Hal tersebut terjadi karena dengan adanya program JKN yaitu pasien rujuk balik (PRB) sehingga banyak pelanggan yang di arahkan ke apotek tersebut oleh rumah sakit untuk menebus obat di apotek tersebut [8].

Tabel 1

Persentase omset apotek tahun 2018 terhadap omset tahun 2014

\begin{tabular}{ccc}
\hline No. & Nama Apotek & \% \\
\hline 1 & OJKN 1 & $-55 \%$ \\
\hline 2 & AJKN 2 & $-36 \%$ \\
\hline 3 & AJKN 3 & $101 \%$ \\
\hline 4 & AJKN 4 & $43 \%$ \\
\hline 5 & AJKN 5 & $19 \%$ \\
\hline
\end{tabular}

Keterangan: Tanda (-) menunjukkan penurunan

Tabel 2

Jumlah kunjungan pelanggan apotek

\begin{tabular}{cccccccc}
\hline \multirow{2}{*}{ No. } & Nama Apotek & \multicolumn{4}{c}{ Jumlah Pelanggan Apotek Per Tahun } & \multirow{2}{*}{ Peningkatan/ } \\
\cline { 3 - 7 } & & $\mathbf{2 0 1 4}$ & $\mathbf{2 0 1 5}$ & $\mathbf{2 0 1 6}$ & $\mathbf{2 0 1 7}$ & $\mathbf{2 0 1 8}$ & \\
Penurunan & $16 \%$ \\
\hline 1 & AJKN1 & 41.200 & 41.900 & 47.700 & 44.100 & 47.800 & $-14 \%$ \\
\hline 2 & AJKN2 & 61.100 & 55.400 & 50.100 & 57.400 & 52.700 & $299 \%$ \\
\hline 3 & AJKN3 & 15.800 & 26.300 & 39.100 & 47.400 & 63.100 & $85 \%$ \\
\hline 4 & AJKN4 & 18.200 & 19.300 & 21.600 & 32.400 & 33.700 & $33 \%$ \\
\hline 5 & AJKN5 & 29.390 & 30.740 & 31.250 & 33.100 & 35.770 & \\
\hline
\end{tabular}

Keterangan: Tanda (-) menunjukkan penurunan

Tabel 3

Nilai Net Profit Margin (NPM) apotek

\begin{tabular}{ccccc}
\hline No. & Nama Apotek & Nilai NPM Tahun 2014 & Nilai NPM Tahun 2018 & Standar \\
\hline 1 & AJKN1 & $6,96 \%$ & $7,20 \%$ & Sesuai \\
\hline 2 & AJKN2 & $6,45 \%$ & $7,86 \%$ & Sesuai \\
\hline 3 & AJKN3 & $7,10 \%$ & $7,80 \%$ & Sesuai \\
\hline 4 & AJKN4 & $6,25 \%$ & $6,28 \%$ & Sesuai \\
\hline 5 & AJKN5 & $4,80 \%$ & $5,53 \%$ & Sesuai \\
\hline
\end{tabular}

Keterangan: Standar NPM apotek $>5 \%$ 


\subsection{Perspektif keuangan}

Berdasarkan hasil perhitungan rasio Net Profit Margin (NPM) pada Tabel 3, diketahui bahwa nilai NPM Apotek AJKN 1 mengalami kenaikan sebesar $0,24 \%$, sedangkan untuk apotek AJKN 2 mengalami kenaikan sebesar 1,41\%, apotek AJKN 3 mengalami kenaikan sebesar 0,70\%, apotek AJKN 4 menglamai kenaikan 0,03\%, dan apotek AJKN 5 mengalami kenaikan sebesar $0,73 \%$ pada tahun 2018 atas tahun 2014 Semakin besar nilai NPM, maka kinerja apotek semakin produktif [9].

Nilai NPM dari apotek dalam penelitian ini pada tahun 2014 adalah 6,31\% dan pada tahun 2018 adalah 6,93\% meningkat $0,62 \%$. Itu berarti secara umum apotek-apotek dalam penelitian ini sudah berhasil melampaui nilai rata-rata dan dapat dikatakan dalam kondisi yang baik. NPM apotek dikatakan baik apabila $>5 \%$. Dan untuk meningkatkan persentase laba bersih dapat ditingkatkan dengan cara menaikkan persentase laba kotor yaitu dengan menaikkan harga atau membeli barang dengan biaya lebih rendah atau mengurangi beban usaha [10].

\subsection{Perspektif pelanggan}

Berdasarkan hasil uji normalitas (Tabel 4), diketahui bahwa nilai signifikansi Asymp. Sig. (2-tailed) sebesar 0,090 pada variabel $\mathrm{X}$ yaitu kehandalan, ketanggapan, empati, fasilitas berwujud (fasilitas apotek), dan jaminan lebih besar dari 0,05. Maka sesuai dengan dasar pengambilan keputusan dalam uji normalitas kolmogorov-smirnov dapat disimpulkan bahwa data berdistribusi normal, sehingga asumsi atau persyaratan normalitas dalam model regresi sudah terpenuhi. Nilai toleransi dari masing-masing variabel (Tabel 5) X1 (kehandalan), X2 (ketanggapan), X3 (empati), X4 (fasilitas berwujud), $\mathrm{X} 5$ (jaminan) $>0,10$ dan masing-masing nilai VIF $<10,00$ sehingga tidak terjadi multikolinearitas dan bisa dilanjutkan ke tahap regresi.

Hasil analisis regresi linier berganda (Tabel 6), menunjukkan bahwa regresi yang dapat menjelaskan ada atau tidaknya hubungan antara variabel bebas dengan variabel terikat serta dapat menginformasikan besarnya pengaruh variabel bebas tersebut terhadap variabel terikat. Berdasarkan hasil penelitian ini, maka persamaan regresi berganda dapat dinyatakan sebagai berikut:

$$
\begin{gathered}
Y=3,965+0,075 X_{1}+0,203 X_{2}+0,019 X_{3}+0,152 X_{4} \\
+0,238 X_{5}+e
\end{gathered}
$$

Berdasarkan model regresi linier berganda tersebut dapat dijelaskan bahwa: (1) Nilai $\alpha$ sebesar 3,965. Konstanta sebesar 3,965 menunjukkan bahwa jika variabel $X$ memiliki nilai 0 , maka variabel $Y$ adalah sebesar 3,965. Artinya jika variabel $X$ dipertimbangkan, maka akan berpengaruh terhadap kepuasan pelanggan apotek. (2) Nilai $\beta_{1}$ sebesar 0,075 ; menunjukkan bahwa jika koefisien regresi variabel kehandalan $\left(\boldsymbol{X}_{\mathbf{1}}\right)$ meningkat sejumlah 1 satuan dengan anggapan variabel lain tetap maka kepuasan pelanggan $(Y)$ akan mengalami kenaikan sebesar 0,075 . Koefisien ini bernilai positif artinya terjadi hubungan positif antara kehandalan dan kepuasan pelanggan, semakin naik nilai kehandalan maka semakin naik kepuasan pelanggan. Apabila kehandalan naik satu satuan maka kepuasan pelanggan terhadap pelayanan kefarmasian akan naik 0,075 . (3) 3. Nilai $\beta_{2}$ sebesar 0,203 ; menunjukkan bahwa jika koefisien regresi variabel ketanggapan $\left(\boldsymbol{X}_{2}\right)$ meningkat sejumlah satu satuan dengan anggapan variabel lain tetap maka kepuasan pelanggan $(Y)$ akan mengalami kenaikan sebesar 0,203 . Koefisien ini bernilai positif artinya terjadi hubungan positif antara ketanggapan dan kepuasan pelanggan, semakin naik nilai ketanggapan maka semakin naik kepuasan pelanggan. (4) Nilai $\beta_{3}$ sebesar 0,019 ; menunjukkan bahwa jika koefisien regresi variabel empati $\left(\boldsymbol{X}_{\mathbf{3}}\right)$ meningkat sejumlah satu satuan dengan anggapan variabel lain tetap maka kepuasan pelanggan $(Y)$ akan mengalami kenaikan sebesar 0,019. Koefisien ini bernilai positif artinya terjadi hubungan positif antara empati dan kepuasan pelanggan, semakin naik nilai empati maka semakin naik kepuasan pelanggan. Apabila empati naik satu satuan maka kepuasan pelanggan terhadap pelayanan kefarmasian akan naik 0,019. (5) Nilai $\beta_{5}$ sebesar 0,238 ; menunjukkan bahwa jika koefisien regresi variabel jaminan $\left(\boldsymbol{X}_{\mathbf{5}}\right)$ meningkat sejumlah satu satuan dengan anggapan variabel lain tetap maka kepuasan pelanggan $(Y)$ akan mengalami kenaikan sebesar 0,238. Koefisien ini bernilai positif artinya terjadi hubungan positif antara jaminan dan kepuasan pelanggan, semakin naik nilai jaminan maka semakin naik kepuasan pelanggan.

\section{Uji Signifikan Simultan (Uji F) \& Uji Beta}

Berdasarkan Tabel 7 , hasil perhitugan menunjukan $\mathrm{F}$ Hitung sebesar 5,111 dan F Tabel sebesar 2,31. Diketahui bahwa F Hitung > F Tabel. Maka dapat disimpulkan bahwa variabel X (Kehandalan, Ketanggapan, Empati, Fasilitas Berwujud, dan Jaminan) secara bersama-sama (simultan) berpengaruh positif dan signifikan terhadap kepuasan pelanggan apotek JKN di kota Makassar. Sehingga dapat diambil kesimpulan bahwa kualitas pelayanan apotek berpengaruh terhadap kepuasan pelanggan apotek di kota Makassar.

Uji beta digunakan untuk mengetahui variabel independen $(X)$ manakah yang lebih dominan diantara variabel independen lainnya terhadap variabel dependen $(Y)$. Nilai beta variabel $X$ yang paling besar diantara variabel $X$ lainnya merupakan variabel $X$ yang berpengaruh paling dominan terhadap $Y$. data dapat disimpulkan bahwa nilai beta $X_{5}$ (Jaminan) $=0,276$ memiliki nilai yang paling besar daripada nilai beta $X_{1}$ (Kehandalan) yaitu $0,115, X_{2}$ (Ketanggapan) yaitu $0,206, X_{3}$ (Empati) yaitu 0,021 dan $X_{4}$ (Fasilitas berwujud) yaitu 0,165 . Maka variabel $X_{5}$ (Jaminan) 
merupakan variabel yang paling dominan terhadap kepuasan pelanggan apotek di kota Makassar.

Peningkatan nilai empati pelanggan dapat dilakukan dengan cara: (1) Meningkatkan perhatian karyawan terhadap pelanggan apotek, (2) meningkatkan empati karyawan terhadap masalah yang dihadapi pelanggan untuk membantu mengurangi rasa cemas pelanggan, (3) karyawan apotek agar lebih bersikap ramah, sopan, dan sabar dalam melayani pelanggan.

Tabel 4

Hasil uji normalitas one-sample Kolmogorov-Smirrnov test

\begin{tabular}{lcr}
\hline & & Unstandardized Residual \\
\hline $\mathbf{N}$ & & 101 \\
\hline \multirow{2}{*}{ Normal Parameters ${ }^{\mathrm{a}, \mathrm{b}}$} & Mean & $0 \mathrm{E}-7$ \\
\hline \multirow{3}{*}{ Most Extreme Differences } & Std. Deviation & .84483060 \\
\cline { 2 - 3 } & Absolute & .124 \\
\hline Kolmogorov-Smirnov Z & Positive & .078 \\
\hline Asymp. Sig. (2-tailed) & Negative & -.124 \\
\hline
\end{tabular}

Tabel 5

Hasil uji multikolinearitas

\begin{tabular}{|c|c|c|}
\hline \multirow{2}{*}{ Model } & \multicolumn{2}{|c|}{ Collinearity Statistics } \\
\hline & Tolerance & VIF \\
\hline \multicolumn{3}{|l|}{ (Constant) } \\
\hline $\mathrm{X} 1$ & .931 & 1.074 \\
\hline $\mathrm{X} 2$ & .770 & 1.298 \\
\hline X3 & .725 & 1.379 \\
\hline $\mathrm{X} 4$ & .862 & 1.160 \\
\hline $\mathrm{X} 5$ & .792 & 1.263 \\
\hline
\end{tabular}

Tabel 6

Hasil uji analisis regresi linier bertingkat

\begin{tabular}{ccc}
\hline \multicolumn{3}{c}{ Unstandardized Coefficients } \\
\hline & B & Std. Error \\
\hline (Constant) & 3.965 & 1.476 \\
\hline X1 & .075 & .062 \\
\hline X2 & .203 & .102 \\
\hline X3 & .019 & .099 \\
\hline X4 & .152 & .090 \\
\hline X5 & .238 & .088
\end{tabular}

Sumber: Output SPSS 20 (2019)

Tabel 7

Hasil uji signifikansi simultan (Uji F)

\begin{tabular}{llllll}
\hline & \multicolumn{1}{c}{ ANOVA $^{\text {a }}$} & & \\
\hline Model & Sum of Squares & Df & Mean Square & F & Sig. \\
\hline Regression & 19.200 & 5 & 3.840 & 5.111 & $.000^{\text {b }}$ \\
\hline Residual & 71.374 & 95 & .751 & & \\
\hline Total & 90.574 & 100 & & & \\
\hline
\end{tabular}

Tabel 8

Sumber: Output SPSS 20 (2019)

Hasil uji beta

\begin{tabular}{ccc}
\hline No. & Model & Standardized Coefficient Beta \\
\hline 1. & $\mathrm{X} 1$ & .115 \\
\hline 2. & $\mathrm{X} 2$ & .206 \\
\hline 3. & $\mathrm{X} 3$ & .021 \\
\hline 4. & $\mathrm{X} 4$ & .165 \\
\hline 5. & $\mathrm{X} 5$ & .276 \\
\hline
\end{tabular}

Sumber: Output SPSS 20 (2019)

\section{Kesimpulan}

Hasil penelitian pada perspektif keuangan menunjukan bahwa rata-rata nilai net profit margin apotek tahun tahun 2014 adalah 6,31\% dan pada tahun 2018 adalah 6,93\% dan bisa dikatakan dalam kondisi baik. Pada omset apotek terdapat 2 apotek yang mengalami penurunan omset apotek dan 3 apotek yang mengalami kenaikan omset apotek tahun 2018 atas tahun 2014.Sedangkan pada jumlah kunjungan pelanggan apotek terdapat 1 apotek yang mengalami penurunan dan 4 apotek yang mengalami kenaikan jumlah kunjungan pelanggan ke apotek tahun 2018 atas tahun 2014. Pada perspektif pelanggan kualitas pelayanan apotek berpengaruh 
terhadap kepuasan pelanggan apotek di kota Makassar dalam era JKN dengan ditunjukan F Hitung sebesar 5,111 dan tabel F sebesar 2,31.

\section{Keterbatasan penelitian}

Dalam penelitian ini peneliti hanya menggunakan 2 perspektif dalam Balanced Scorecard dari 4 perspektif yang ada. Serta dalam perspektif keuangan hanya menggunakan 1 variabel (Penjelasan Balanced Scorecard ada di pendahuluan).

\section{Daftar pustaka}

[1] Presiden Republik Indonesia. Undang-undang Republik Indonesia Nomor 24 tahun 2011 Tentang Badang Peyelenggaraan Jaminanan Sosial. 2011.

[2] Kementerian Kesehatan Republik Indonesia. Peraturan Menteri Kesehatan Republik Indonesia Nomor 9 Tahun 2017 Tentang Apotek. 2017.

[3] Kementerian Kesehatan Republik Indonesia. Peraturan Menteri Kesehatan Republik Indonesia Nomor 71 tahun 2013 tentang Pelayanan Kesehatan pada Jaminan Kesehatan Nasional. 2013.

[4] Yuningsih Yati, 2008. Evaluasi Kinerja Apotek Mitra Sehat Colamadu Karanganyar Dengan Perspektif Customer dan Keuangan. UMS

[5] Anief, M., 2014, Manajemen Farmasi, Cetakan keempat. Gadjah Mada University Press, Yogyakarta.

[6] Kaplan, R.S. and Norton, D.P., 2000, Balanced Scorecard:Menerapkan Strategi Menjadi Aksi, diterjemahkan oleh Peter R. Yosi Pasla, Erlangga, Jakarta.

[7] Tjiptono,dkk. 2011. Service quality and satisfaction (ed 3). Yogyakarta.

[8] Kementerian Kesehatan Republik Indonesia. Buku Pegangan Sosialisasi Jaminan Kesehatan Nasional (JKN) dalam Sistem Jaminan Sosial Nasional. 2013.

[9] Seto, S., 2001, Manajemen Apoteker, Airlangga University Press, Surabaya

[10] Anwarudin Wawang, 2013. Analisis Kinerja Unit Bisnis Apotek Perusahaan Daerah Farmasi Ciremai Kota Cirebon Dengan Menggunakan Balanced Scorecard Sebagai Bahan Penyusunan Strategy Maps.J.MPF. hal 291-310 